\title{
Financial feasibility of livestock feed business from palm oil plantation wastes
}

\author{
Yoshi Tri Sulistyaningsih ${ }^{1 *}$, Bambang Haryanto ${ }^{2}$, and Lintje Hutahaean ${ }^{1}$ \\ ${ }^{1}$ Indonesian Center for Agricultural Technology Assessment and Development (ICATAD), Indonesia \\ ${ }^{2}$ Asssessment Institute for Agricultural Technology (AIAT) Central Kalimantan, Indonesia
}

\begin{abstract}
There are three types of livestock feed as palm oil by-product, namely feed for fattening, feed for breeding and concentrates. This study aims to analyze the finansial feasibility of producing feed from palm oil waste and to analyze the added value of product from bio-industrial agricultural based on palm oil-cattle. This study was conducted in farmer group of bio-industrial agriculture in Sumber Makmur, Parenggean, Kotawaringin, Central Kalimantan, in December 2019. Data collection was carried out through Focus Group Discussion. To analyze the finansial feasibility, used investment criteria: net benefit-cost ratio, break even point, and payback period, while to determine the added value of the product, used the Hayami method. The result showed that from net B/C ratio, BEP (rupiah and unit), and payback period, the business of animal feed for fattening, breeding, and concentrates are profitable. Among the three business of feed, business feed for fattening is more profitable than others. The ratio of the added value of each livestock feed business between 0,89-0.94. The result of the study showed that the three of feed business were feasible to develop. It can be considered by other farmer groups and investors to develop livestock feed business from oil palm cultivation waste.
\end{abstract}

\section{Introduction}

The need for food, feed and energy is currently increasing while the production of raw materials tends to decrease [1]. The development of the livestock industry requires the availability of continuous feed, as well as the people's livestock business. The scarcity of grass as forage for livestock is a problem faced by farmers, especially during the dry season. Other feed alternatives are needed to suffice animal feed while still containing the nutrients needed by livestock. Agricultural and plantation waste can provide feed for large ruminants, one of which is cattle. Oil palm plantation waste in the form of fronds can be used as an alternative feed to substitute forage for animal feed. Oil palm plantation biomass has great potential as cattle feed, but it has not been used optimally. The waste has a high crude fiber content but its availability is abundant so that it can be used as animal feed material through a touch of technology, be a safe feed for consumption [2].

Oil palm plantations are most widely distributed on the islands of Sumatra and Kalimantan. In Central Kalimantan, the area of oil palm plantations in 2020 is estimated to

* Corresponding author: yoshi trisulistya@yahoo.com 
be 1.7 million hectares [3]. The area is a potential for cattle development by utilizing palm oil plantation waste in the form of fronds and crude palm oil (CPO) processing waste as a source of animal feed. Farmers in Sumber Makmur Village, Parenggean District, East Kotawaringin Regency, Central Kalimantan are cooperating farmers in bio-industry activities. Most of their livelihoods are farmers in oil palm plantations, and have cows as an additional income. Feed constraints are also a problem faced by farmers. The bioindustry system based on palm-cattle has the potential to be developed. Animal feed bioindustry is developed from oil palm plantation biomass, including palm fronds and leaves, palm kernel and solids [4]. By utilizing palm oil plantation waste, the Jaya Makmur farmer group processes it into feed which is not only to fulfill the group's livestock needs, but also to be sold commercially.

Palm fronds and leaves that can be used as a substitute for forage, contain crude fiber content of $50.9 \%$ and $21.5 \%$, respectively. The levels of lignin are quite high, namely $17.4 \%$ and $27.6 \%$, so that before being given to livestock as feed, treatment is needed to increase consumption and palatability. Previous research showed that oil palm fronds can be used as feed as much as $30 \%$ of the total feed, with a composition of $30 \%$ oil palm and $70 \%$ concentrate. Palm fronds can be used as a substitute for grass [5].

There are three types of feed produced from the processing of palm oil waste, namely feed for breeding, feed for fattening and concentrate. This feed processing business has been carried out for four years and the product is accepted by the market, so it is very prospective to be produced continuously. The purpose of this study was to analyze the financial feasibility of animal feed production from palm oil plantation waste and to determine the added value by product bioindustrial agricultural based on palm oil-cattle.

\section{Research methods}

The data used are primary and secondary data. Primary data obtained from direct observation to determine the technique of processing raw materials into feed. Collecting data through interviews with farmers who process the feed. The data collected are raw materials used, processes, quantities and prices of raw materials and labor, and production results. Secondary data is obtained from literature studies from various sources, number of products and market prices. The research was conducted at the Jaya Makmur farmer group in Sumber Makmur Village, Parenggean District, East Kotawaringin Regency. Research and data collection was carried out in November 2019.

Quantitative data analysis used to measure business feasibility by the criteria of BenefitCost Ratio (B/C), Payback Period (PP), and Internal Rate of Return (IRR). Net B/C (Benefit Cost Ratio) is the criteria used in a farming project. A farm is declared to provide benefits if the $B / C$ value $>1$, where $B=$ profit, $C=$ costs, $i=$ the prevailing interest rate and $t=$ duration of farming, as formulated in equations (1) and (2).

$$
\mathrm{B} / \mathrm{C}=\frac{\text { Present value } \mathrm{B}}{\text { Present value } \mathrm{C}} \quad B / C=\frac{B(1+i)^{t}}{C(1+i)^{t}}
$$

BEP (break even point), is the analysis showing the relationship between fixed costs, variable costs, profits and minimum sales volume that must be maintained so as not to experience losses, as formulated in equation (2), where $\mathrm{FC}=$ fixed costs, $\mathrm{VC}=$ variable cost, $\mathrm{S}=$ net sales, $\mathrm{P}=$ price per unit of product, and $\mathrm{V}=$ variable cost per unit. 


$$
\mathrm{BEP}(\text { Rupiah })=\frac{F C}{1-\frac{V C}{S}} \quad \mathrm{BEP}(\text { Unit })=\frac{F C}{P-V}
$$

PP (Payback Period), is a feasibility criterion by comparing the payback period with the target length of return on investment. If the PP is smaller than the investment return target, meaning worth working on.

$$
\mathrm{PP}=\frac{\text { Investasi }}{\text { Annual cash flow }}
$$

Some of the assumptions used in this research into the feasibility analysis of the animal feed business include: 1) the project age from the feasibility analysis is 10 years, 2) the overall investment costs are incurred in year 0 . Operational costs, which consist of fixed costs and variable costs, are incurred in the 1st year where production activities begin, 3) depreciation is calculated based on the calculation using the straight-line method, by calculating the purchase value divided by economic life, 4) the level of input prices and output prices are assumed the same from the beginning to the end of the project, inflation and other factors are considered constant (ceteris paribus), 5) the discount rate used is the one-year loan interest rate at bank which is $12 \%, 6$ ) The feed produced are assumed to be all sold to buyers/markets. To analyze the added value of the product, used the Hayami method.

\section{Results and discussion}

\subsection{Feasibility analysis of animal feed business}

Efforts to fulfill feed needs are to utilize locally available feed ingredients in abundance. The palm oil industry, from plantations to processing products, is a potential source of feed. Innovations of making complete feed and concentrated are very helpful for farmers in fulfilling feed continuously, in addition to reducing costs. The implementation of cattle-palm integration can be improved by utilizing palm oil waste [6].

Processing palm oil waste into feed has been carried out by the Jaya Makmur farmer group since 2017 through AIAT assistance in bio-industry activities. There are three types of animal feed produced, namely feed for fattening, feed for breeding and concentrates. The production capacity of each feed produced is 30 tons/month; 60 tons/month and 30 tons/month.

Complete feed or concentrate needs to be given to breeding and fattening businesses to stimulate body weight gain, improve milk quality and maintain calf health [7]. The monthly production of feed for fattening and breeding is $36,000 \mathrm{~kg}$ each, while for concentrate feed is $48,000 \mathrm{~kg}$. The selling price for fattening feed is $\mathrm{Rp} .1,400 / \mathrm{kg}$, feed for breeding is $\mathrm{Rp}$. $1,200 / \mathrm{kg}$, and concentrate feed is Rp. $1,800 / \mathrm{kg}$. The highest variable cost used for the three feed businesses is the cost of oil palm meal by $23-37 \%$.

In concentrate feed, the second largest cost is the use of bran, which is $28.77 \%$ of the total cost. The addition of palm kernel to the animal feed component can affect the daily body weight gain $(\mathrm{PBBH})$ of livestock, so that it is more economical than other feeds $[8,9]$. The addition of by-products palm oil industry is added to increase its consumption and digestibility [10]. Animal feed business financial analysis is presented in Table 1. 
Table 1. Finansial analysis of feed business from palm oil plantation waste, 2019

\begin{tabular}{|c|c|c|c|c|}
\hline No. & Description & Fattening feed & Breeding Feed & Concentrate \\
\hline \multirow[t]{3}{*}{ A. } & Revenue (Rp) & 50.400 .000 & 43.200 .000 & 86.400 .000 \\
\hline & Production (kg/month) & 36.000 & 36.000 & 48.000 \\
\hline & Price $(\mathrm{Rp} / \mathrm{kg})$ & 1.400 & 1.200 & 1.800 \\
\hline \multirow[t]{26}{*}{ B. } & Total cost (explicit) (Rp) & 30.496 .556 & 28.475 .240 & 70.065 .680 \\
\hline & Variable cost $(\mathrm{Rp})$ & 29.752 .056 & 27.730 .740 & 69.583 .680 \\
\hline & - oil palm fronds & 594.000 & 675.000 & 0 \\
\hline & - oil palm meal & 11.102 .400 & 6.566 .400 & 26.496 .000 \\
\hline & - solid palm & 660.600 & 684.000 & 744.000 \\
\hline & - onggok & 2.071 .656 & 2.927 .340 & 1.601 .280 \\
\hline & - bran & 0 & 0 & 20.160 .000 \\
\hline & - drops & 1.215 .000 & 1.620 .000 & 4.320 .000 \\
\hline & - chalk & 129.600 & 259.200 & 230.400 \\
\hline & - salt & 216.000 & 216.000 & 384.000 \\
\hline & - minerals & 1.080 .000 & 1.080 .000 & 3.360 .000 \\
\hline & - starbio & 2.700 .000 & 3.600 .000 & 2.400 .000 \\
\hline & - urea & 334.800 & 334.800 & 744.000 \\
\hline & - thread & 36.000 & 36.000 & 48.000 \\
\hline & - chopper fuel & 780.000 & 900.000 & 0 \\
\hline & - plastic & 3.960 .000 & 3.960 .000 & 3.960 .000 \\
\hline & - fuel mixer & 792.000 & 792.000 & 1.056 .000 \\
\hline & - labor costs & 4.080 .000 & 4.080 .000 & 4.080 .000 \\
\hline & Fixed cost (Rp) & 744.500 & 744.500 & 482.000 \\
\hline & $\begin{array}{l}\text { - administrative costs, } \\
\text { communications, } \mathrm{PBB}\end{array}$ & 150.000 & 150.000 & 150.000 \\
\hline & - electricity & 72.000 & 72.000 & 72.000 \\
\hline & $\begin{array}{l}\text { Machine maintenance } \\
\text { costs (Rp) }\end{array}$ & & & \\
\hline & - grind grinder/month & 112.500 & 112.500 & 0 \\
\hline & - crab eyes/month & 150.000 & 150.000 & 0 \\
\hline & - oil/month/engine & 60.000 & 60.000 & 60.000 \\
\hline & $\begin{array}{c}\text { - machine maintenance/ } \\
\text { month } / 2 \text { machines }\end{array}$ & 200.000 & 200.000 & 200.000 \\
\hline \multirow[t]{4}{*}{$\mathrm{C}$. } & Fixed cost (implicit) (Rp) & 1.266 .667 & 1.266 .667 & 850.000 \\
\hline & Shreeder machine shrinkage & 416.667 & 416.667 & \\
\hline & Mixer shrinkage & 391.667 & 391.667 & 391.667 \\
\hline & Building shrinkage & 458.333 & 458.333 & 458.333 \\
\hline D. & Income (A-B) & 19.903 .444 & 14.724 .760 & 16.334 .320 \\
\hline E. & Profit (D-C) & 18.636 .777 & 13.458 .093 & 15.484 .320 \\
\hline
\end{tabular}

Source: Primary data analysis (2021)

Of the three businesses animal feed, it shows that all three generate profits for farmers. The highest profit is obtained in the animal feed business for fattening, then concentrate feed 
and the lowest profit is feed for cattle breeding. Greater demand than production capacity will be profitable in business, in addition to abundant raw materials and adequate labor [11]. To determine the feasibility of the animal feed business, a financial analysis was carried out using the criteria of Net B/C, BEP, and PP. The results of the analysis are as shown in Table 2.

Table 2. Feasibility analysis of feed business from palm oil plantation waste, 2019

\begin{tabular}{|l|l|l|l|l|}
\hline No & \multicolumn{1}{|c|}{ Description } & Fattening Feed & Breeding Feed & \multicolumn{1}{c|}{ Concentrate } \\
\hline 1. & Net B/C (Net Benefit Cost ratio) & 1,50 & 1,36 & 1,19 \\
\hline 2. & Break Even Point (rupiah) & 4.909 .099 & 5.616 .455 & 6.843 .638 \\
\hline & Break Even Point (Unit) & 3.506 & 4.680 & 3.802 \\
\hline 3. & Payback Period & third month & fourth month & sixth month \\
\hline
\end{tabular}

Source: Primary data analysis (2021)

The table above shows that the three animal feeds are financially feasible. From the net $\mathrm{B} / \mathrm{C}$ value, it is known that animal feed for fattening, breeding and concentrates is $1.5 ; 1.36$ and 1.19. Based on the BEP value, it is known that the BEP value both in rupiah and minimum unit is in the feed business for fattening is the most feasible.

The fastest return on investment or payback period is in the fattening animal feed business, followed by breeding feed and finally concentrate feed for 3 months each; 4 months and 6 months. Based on the three investment criteria, it is known that feed business for fattening is more feasible than the other two. Bioindustry of animal feed taken from oil palm biomass: palm fronds and leaves, palm kernel and solids has the potential to be developed [4]. The implementation of technology in plantation and livestock businesses can increase farmers' income through the use of available inputs [12].

\subsection{Value added analysis of animal feed business}

The analysis of the added value of the product using the Hayami method for each feed business, it is shown in table 3.

Table 3. Analysis of the added value of animal feed business from palm oil plantation waste, 2019

\begin{tabular}{|l|l|c|c|c|}
\hline & \multicolumn{1}{|c|}{ Calculation Element } & Fattening feed & Nursery feed & Concentrate \\
\hline 1. & Production & 1.500 & 1.500 & 2.000 \\
\hline 2. & Raw material & 150 & 177,6 & 264,3 \\
\hline 3. & Labor & 8 & 8 & 8 \\
\hline 4. & Conversion factor & 10 & 8 & 8 \\
\hline 5. & Labor coefficient (\%) & 0,053 & 0,045 & 0,030 \\
\hline 6. & Product Price & 1.400 & 1.200 & 1.800 \\
\hline 7. & Average wage & 85.000 & 85.000 & 85.000 \\
\hline 8. & Raw material prices & 826 & 770 & 1.450 \\
\hline 9. & Other inputs & 14.000 & 0 & 0 \\
\hline 10. & Production value & 13.174 & 10.133 & 13.622 \\
\hline 11. & a. Value-added & 0,94 & 9.363 & 12.172 \\
\hline & b. Value added ratio (\%) & 4.533 & 0,92 & 0,89 \\
\hline 12. & a. Labor rewards (Rp) & 0,344 & 3.828 & 2.573 \\
\hline & b. Labor section (\%) & 8.641 & 0,409 & 0,211 \\
\hline 13. & a. $\quad$ Advantage & 0,656 & 5.535 & 9.599 \\
\hline & b. Profit rate (\%) & 13.174 & 0,591 & 0,789 \\
\hline 14. & Processing Margin & 9.363 & 12.172 \\
\hline
\end{tabular}

Source: Primary data analysis (2021) 
From the calculation results shows that the value added ratio for fattening, nursery and concentrate feed products is $0.94 ; 0.92$ and 0.89 . This value indicates that the three animal feed businesses are classified as high according to the indicator that if the added value ratio is greater than $40 \%$, meaning the business have high added value for each $\mathrm{kg}$ of product. Both bio-industry activities and the integration of oil palm-cattle can improve the welfare of farmers through sustainable business management [13].

In developing the integration of oil palm-cow and producing its by-products, there are several obstacles faced, namely tend to be traditional, lack of human resource skills and lack of supporting infrastructure [14]. However, the effort to integrate oil palm-cattle is feasible [15], likewise business of processing by-products of oil palm plantations into animal feed. For the sustainability of animal feed, independent farmers are needed in processing feed. The Indicators of farmer independence are self-development, management skills and social skills [16]. In order for a business to be sustainable, good management is needed from the economic, social and environmental aspects [17].

\section{Conclusions}

This animal feed business from palm oil waste is feasible to be developed (profitable) with the net $\mathrm{B} / \mathrm{C}$ between 1.19 to 1.50 and an added value between 0.89-0.94. Among the three animal feed businesses, the most feasible is animal feed business for fattening. This business still needs to be accompanied by researchers and extensions worker from AIAT and from the agricultural service in term of technological innovation, and institusional strengthening especially marketing. Support from the local goverment is needed in promoting this bussiness to stakeholder and user from inside and outside district. Bussiness development is needed because the feed produced is a solution in overcoming the main problem of farmers, namely the scarcity of feed during dry season. In addition, local government need to play an active role in the continuity of this business as an effort towards sustainable agriculture because it is not only economically beneficial but also has a good impact on the environment.

\section{References}

1. A.P Sinurat, I.W. Mathius, T. Purwadaria, "Pengolahan dan Pemanfaatan hasil Samping Industri Sawit sebagai Bahan Pakan," (Jakarta, IAARD press, 2012)

2. A. Suryana, Darmawan, M. Yasin, Prosiding Seminar Nasional Peternakan Ramah Lingkungan, Makassar 19-20 Juni 2014. Buku I Balai Besar Pengkajian dan Pengembangan Teknologi Pertanian, Bogor, (2014)

3. Ditjenbun, Statistik perkebunan Indonesia 2018-2020, (Jakarta: Direktorat Jenderal Perkebunan, 2019)

4. Gunawan, C. Thalib, Wartazoa, 24 (2014)

5. S. Oshio, M.J. Daud, A.H. Osman, JARQ, 25 (1988)

6. Argo, K. Rahardjo, K.P. Wicaksono, E-Journal Universitas Brawijaya, 9 (2015)

7. Suryana, M. Yasin, Jurnal Litbang Pertanian, 34 (2015)

8. N.R. Bariroh, S.G. Gunawan, Suryani, Prosiding Seminar Nasional Agroinovasi Spesifik Lokasi Untuk Ketahanan Pangan pada Era Masyarakat Ekonomi ASEAN, Bandar Lampung, 19-20 Oktober 2016. Universitas Lampung, Lampung, (2016)

9. A. Rizali, Fahcrianto, M.H. Ansari, A. Wahdi, Enviro Scienteae, 14 (2018)

10. W.H. Kum, M.W. Zahari, Journal Palm Oil Res, 23 (2011)

11. S.R. Nurmalina, T. Sarianti, Feryanto, Jurnal Managemen dan Agribisnis, 9 (2012) 
12. D. Yuliani, Jurnal Agroteknologi, 4 (2014)

13. R. Sulistiawati, N. Kusrini, Imelda, Jurnal Ekonomi Kuantitatif Terapan, 11 (2018)

14. A.B. Santoso, Jurnal Ilmu Pertanian Indonesia, 22 (2017)

15. N. lham, S. Handewi, Jurnal Analisis Kebijakan Pertanian, 9 (2011)

16. M. Toha, A. Musyadar, Jurnal Penyuluhan Pertanian, 9 (2014)

17. D. Agustina, Hariyadi, Saharuddin, Journal of natural Resources and Environmental Management, 4 (2014) 